\title{
Kesiapan Mahasiswa LPTK Swasta di Semarang Menjadi Guru Matematika yang Profesional
}

\author{
Saifan Sidiq Abdullah \\ Jurusan Pendidikan Matematika, Universitas Nahdatul Ulama Pekalongan. Jalan Raya Karangdowo \\ No. 09, Karangwuni Pekalongan 51173, Indonesia \\ Email: saifanshidiq@gmail.com, Telp: +62285-785903
}

Received: 20 May 2017; Revised:7 June 2017; Accepted: 10 June 2017

\begin{abstract}
Abstrak
Penelitian ini bertujuan untuk mendeskripsikan kesiapan mahasiswa LPTK swasta menjadi guru matematika yang profesional. Penelitian ini merupakan penelitian mixed method dengan desain sequential explanatory strategy. Populasi dan sampel pada penelitian ini adalah mahasiswa pendidikan matematika semester 8 LPTK swasta di Semarang. Kesiapan menjadi guru matematika yang profesional dinilai melalui tiga aspek yaitu pengetahuan, sikap, dan keterampilan. Analisis data deskriptif menggunakan kecenderungan kesiapan dalam lima kriteria, yaitu sangat siap, siap, cukup, kurang, dan sangat kurang. Hasil penelitian menunjukkan bahwa kesiapan mahasiswa LPTK swasta di Semarang ditinjau dari: (1) pengetahuan profesional masuk dalam kategori kurang, (2) keterampilan profesional masuk dalam kategori siap, dan (3) sikap profesional masuk dalam kategori siap untuk menjadi (calon) guru matematika yang profesional. Secara umum, kesiapan mahasiswa LPTK swasta di Semarang menjadi guru matematika yang profesional masuk dalam kategori cukup.
\end{abstract}

Kata Kunci: kesiapan mahasiswa, pengetahuan profesional, keterampilan profesional, sikap profesional

\section{The Readiness of Private Pre-Service Teachers in Semarang to be Professional Math Teachers}

\begin{abstract}
This research aimed to describe the readiness of private pre-service teacher in Semarang to be professional mathematics teachers. This was a mixed method study using the Sequential Explanatory Strategy. The population was all the $8^{\text {th }}$ semester private math pre-service teachers in Semarang. The descriptive data analysis categorized performance trend into five criteria: very ready, ready, fairly ready, poor, and very poor. The results show that the readiness of private pre-service teachers in terms of: (1) professional knowledge were in Poor category, (2) professional skills were in Ready category, and (3) the professional attitudes were in ready to be professional mathematics teachers. Generally, the readiness of private pre-service teachers to be professional math teachers were in fairly ready category.
\end{abstract}

Keywords: preservice teachers readiness, professional knowledge, professional skills, professional attitudes

How to Cite: Abdullah, S. (2017). Kesiapan mahasiswa LPTK swasta di Semarang menjadi guru matematika yang profesional.PYTHAGORAS: Jurnal Pendidikan Matematika, $12(1), \quad 87-97$. doi:http://dx.doi.org/10.21831/pg.v12i1.14051

Permalink/DOI: http://dx.doi.org/10.21831/pg.v12i1.14051 


\section{PENDAHULUAN}

Pendidikan memiliki peran utama dalam menyiapkan sumber daya manusia yang unggul dan kompeten untuk menghadapi berbagai tantangan di era globalisasi. Pendidikan juga menjadi salah satu indikator penilaian kemajuan suatu bangsa. Suatu negara terkategori negara maju, negara berkembang, atau bahkan negara terbelakang dapat dilihat berdasarkan kondisi pendidikannya. Tujuan pendidikan di Indonesia yang tercantum dalam Undang-undang Nomor 20 tahun 2003 tentang Sistem Pendidikan Nasional adalah untuk mengembangkan potensi peserta didik agar menjadi manusia yang beriman dan bertakwa kepada Tuhan Yang Maha Esa, berakhlak mulia, sehat, berilmu, cakap, kreatif, mandiri, dan menjadi warga negara yang demokratis serta bertanggung jawab (Republik Indonesia, 2003). Pada umumnya, pendidikan bertujuan untuk menghasilkan sumber daya manusia yang kompeten dan profesional yang pada nantinya akan bisa memenuhi berbagai bidang dalam proses membangun sebuah negara menjadi negara yang maju.

Pendidikan harus mampu memberikan bekal kepada peserta didik berkaitan dengan segala aspek kehidupan. Salah satu aspek yang sangat penting dan harus dikuasai oleh peserta didik adalah matematika. Dalam Permendiknas Nomor 22 Tahun 2006 disebutkan bahwa tujuan pendidikan matematika adalah membekali peserta didik dengan kemampuan berpikir logis, analitis, sistematis, kritis, dan kreatif, serta kemampuan bekerjasama. Kompetensi tersebut diperlukan agar peserta didik memiliki kemampuan dalam memperoleh, mengelola, dan memanfaatkan informasi untuk bertahan hidup pada keadaan yang selalu berubah, tidak pasti, dan kompetitif.

Pendidikan matematika yang ideal menurut NCTM (2000, p.3) adalah kemampuan dalam memberikan pembelajaran matematika yang bermakna, siswa mampu merepresentasikan pengetahuan matematika secara utuh, siswa mampu mengkomunikasikan ide dan hasil belajarnya baik secara lisan dan tertulis secara efektif, dan siswa mampu menghargai dan menggunakan pembelajaran secara aktif. Sementara itu, menurut Permendiknas Nomor 22 Tahun 2006, guru matematika harus bisa mewujudkan pembelajaran matematika yang efektif, sehingga peserta didik mampu memahami konsep matematika, menggunakan penalaran- nya, memecahkan masalah, mengomunikasikan gagasan, dan memiliki sikap menghargai kegunaan matematika dalam kehidupan. Berkaitan dengan hal tersebut, Muzaffar, Rahim, \& Jessee (2011, p.2) menyatakan bahwa untuk menjadi guru yang efektif, diperlukan pengetahuan (konten dan pedagogik), keterampilan, dan sikap yang memadai. Berdasarkan uraian di atas, dapat disimpulkan bahwa kompetensi guru berperan penting untuk mewujudkan pendidikan matematika yang efektif dan sesuai dengan tujuan yang telah ditetapkan.

Pendidikan matematika yang ideal belum berjalan dengan baik. Hal ini dibuktikan dengan data yang mengindikasikan bahwa pendidikan matematika di Indonesia belum maksimal. Berdasarkan data hasil UN tahun 2014 dari Badan Nasional Standar Pendidikan (BNSP) bahwa mata pelajaran matematika menjadi mata pelajaran yang paling rendah nilainya dibandingkan dengan mata pelajaran lain. Provinsi yang meraih nilai UN paling rendah pada mata pelajaran matematika adalah Provinsi Bengkulu. Selain itu, Provinsi Jawa Tengah menjadi salah satu provinsi yang nilai rata-rata mata pelajaran matematikanya paling rendah jika dibandingkan dengan provinsi lain di Pulau Jawa.

Berdasarkan data dari Dinas Pendidikan Provinsi Jawa Tengah, rata-rata nilai hasil Ujian Nasional (UN) SMP/MTs tahun 2014 adalah 6,61. Nilai ini merupakan nilai terendah jika dibandingkan dengan nilai pada mata pelajaran lain. Selain itu, nilai rata-rata hasil UN SMA/ MA program IPA dan IPS serta SMK di Semarang secara berurutan adalah $7,11,6,66$ dan 6,74 . Nilai ini juga menjadi nilai terendah jika dibandingkan dengan nilai pada mata pelajaran yang lain. Hal tersebut mengindikasikan bahwa kemampuan matematika siswa sekolah menengah di Jawa Tengah masih menjadi masalah yang harus diselesaikan. Nilai UN 2014 mata pelajaran matematika yang rendah menunjukkan adanya masalah dengan kualitas pendidikan matematika di Indonesia.

Salah satu penyebab rendahnya kualitas pendidikan matematika di Indonesia adalah kurangnya guru profesional (Widyani, 2010; Syah, 2013; Rusman, 2013; Mulyasa, 2013). Meskipun guru bukan satu-satunya faktor penentu keberhasilan pendidikan, tetapi proses pembelajaran merupakan titik sentral pendidikan. Guru secara langsung berperan dalam melaksanakan proses pembelajaran terhadap siswa. Guru profesional mutlak diperlukan untuk kemajuan pendidikan. Melalui bimbingan 
guru yang profesional, peserta didik mampu menjadi sumber daya manusia yang berkualitas, kompetitif, dan produktif sebagai salah satu aset bangsa dalam menghadapi persaingan yang makin ketat dan berat sekarang dan di masa datang (Pembukaan Kode Etik Guru). Dalam Undang-undang Nomor 14 Tahun 2005 tertulis bahwa guru yang profesional wajib memiliki 4 kompetensi, yaitu kompetensi pedagogik, kompetensi kepribadian, kompetensi sosial, dan kompetensi profesional.

Salah satu dampak diberlakukannya MEA (Masyarakat Ekonomi Asean) pada akhir 2015 adalah semakin ketatnya persaingan tenaga kerja, termasuk lingkup guru matematika. Selain itu, tantangan juga datang dari dunia internasional dimana pendidikan akan selalu maju dan berkembang. Berkaitan dengan hal tersebut, guru-guru di Indonesia harus mempersiapkan diri dengan baik agar mampu bersaing di ranah internasional. Oleh karena itu, kompetensi guru di Indonesia perlu diselaraskan dengan kompetensi guru yang berlaku secara internasional, melipwuti pengetahuan, keterampilan, dan sikap.

Beberapa hasil penelitian menunjukkan bahwa masih banyak guru yang belum menguasai kompetensi guru profesional. Padahal kompetensi ini diperlukan guru untuk melaksanakan tugasnya sebagaimana yang tertuang dalam UU Nomor 20 Tahun 2003 Pasal 39, yaitu merencanakan pembelajaran, menilai hasil pembelajaran, melakukan bimbingan, melakukan pelatihan, melakukan penelitian, dan melakukan pengabdian masyarakat. Widyani (2010) menyatakan bahwa Indonesia masih mempunyai tugas besar untuk meningkatkan kualitas guru. Masih banyak guru yang memiliki motivasi kerja yang rendah (Supriyo, 2015, p.26). Selain itu, jumlah guru yang mampu mengembangkan diri juga masih sangat sedikit (Wibowo \& Jailani, 2014, p.214).

Indikasi lain dari masih perlunya dilakukan peningkatan kompetensi guru dapat dilihat dari rata-rata hasil Uji Kompetensi Guru (UKG) secara nasional pada tahun 2015 yang masih belum optimal, yaitu pada angka 53,02. Jika ditinjau dari pengetahuan pedagogik, ratarata nasionalnya adalah 48,94. Hal ini menunjukkan bahwa Indonesia masih krisis akan kualitas guru yang profesional. Jika dikaitkan antara data nilai rata-rata $\mathrm{UN}$ mata pelajaran matematika dan hasil UKG di Indonesia, dapat disimpulkan bahwa guru-guru matematika di Indonesia, khususnya wilayah Jawa Tengah, masih banyak yang belum menjadi guru matematika yang profesional.

Masalah tentang kualitas guru yang masih rendah harus segera diselesaikan. Menurut Chotimah (2009, pp.1-2), untuk menghasilkan (calon) guru yang profesional diperlukan peranan dari Lembaga Pendidikan Tenaga Kependidikan (LPTK). LPTK telah diberi tanggung jawab oleh pemerintah untuk menghasilkan guru yang profesional sepertinya belum berjalan secara maksimal. Townsend \& Bates $(2007$, p.3) menyebutkan bahwa LPTK mendapatkan banyak kritik dari berbagai pihak selama dekade terakhir, dengan isu tentang kualitas guru sebagai pusat kritikan. Data tersebut mengindikasikan bahwa LPTK belum maksimal dalam mencetak guru yang profesional. Akan tetapi, menurut Mulyasa (2013, p.10) salah satu faktor yang menyebabkan rendahnya profesionalisme guru adalah adanya kemungkinan Perguruan Tinggi swasta yang mencetak guru asal jadi, atau setengah jadi, tanpa memperhitungkan output kelaknya di lapangan.

Dengan adanya aturan yang menyatakan bahwa guru harus minimal lulus D4/S1, maka fungsi LPTK menjadi sangat sentral dalam menentukan kualitas guru maupun calon guru. Tugas pokok LPTK menurut Undang-undang Nomor 14 Tahun 2005 dan PP Nomor 8 Tahun 2009 adalah untuk menyelenggarakan program pengadaan pendidik dan tenaga kependidikan lainnya pada pendidikan anak usia dini, pendidikan dasar, dan pendidikan menengah, serta untuk menyelenggarakan dan mengembangkan ilmu kependidikan dan non-kependidikan. Program-program dalam LPTK bertujuan untuk menyediakan calon guru yang terampil dan profesional (Smith, 2005, p.3). Karena LPTK memiliki peran yang penting dalam menyiapkan guru yang profesional, maka program pengembangan profesional guru harus disiapkan dengan baik. Pengembangan profesionalisme guru ini bertujuan membekali calon guru agar profesional dalam pengetahuan, profesional dalam keterampilan, dan profesional dalam sikap. Namun jika melihat statitstik jumlah LPTK di Indonesia, jumlah LPTK swasta jauh lebih banyak dibandingkan dengan LPTK negeri. Hal ini menunjukkan bahwa LPTK swasta memiliki peran yang lebih besar dalam menentukan keberhasilan dan kegagalan dalam memenuhi kebutuhan guru matematika yang profesional di Indonesia.

Azhar (2011, p.2) menyatakan bahwa kondisi LPTK di Indonesia saat ini belum siap 
untuk menghasilkan guru yang profesional. Hilgard \& Bower (1975, p.33) juga menambahkan bahwa kegagalan LPTK dalam menghasilkan calon guru yang profesional bergantung pada kesiapan. Kesiapan guru bergantung pada pengetahuan, keterampilan, sikap, dan minat (Jusoh, 2012, p.101). Berdasarkan uraian tersebut, dapat disimpulkan bahwa kurang siapnya LPTK berdampak pada profesionalisme calon guru yaitu pada aspek pengetahuan, keterampilan, sikap.

Kondisi LPTK swasta dan mahasiswa calon guru matematika menjadi fokus dalam penelitian ini. LPTK swasta yang paling berkontribusi dalam menyediakan guru matematika di Jawa Tengah adalah LPTK swasta di Semarang. Berdasarkan hasil tracer study beberapa LPTK swasta di Semarang pada lima tahun terakhir menunjukkan bahwa hampir semua lulusan LPTK di Semarang menjadi guru di sekolah-sekolah di Jawa Tengah. Selain berperan dalam menghasilkan calon guru yang profesional, LPTK swasta juga harus selalu memonitor dan mengevaluasi kualitas mahasiswa secara berkelanjutan. Proses ini sangat penting karena LPTK swasta di Semarang setiap tahunnya meluluskan ratusan calon guru matematika yang disiapkan untuk menjadi guru matematika yang profesional.

\section{METODE}

Jenis penelitian ini adalah penelitian deskriptif dengan metode kombinasi (mixed methods). Pendekatan kuantitatif digunakan sebagai landasan untuk melakukan penelitian lebih mendalam secara kualitatif. Pendekatan kuantitatif dilakukan untuk mengetahui kesiapan mahasiswa LPTK swasta di Semarang menjadi guru matematika yang profesional. Pendekatan kualitatif dilakukan untuk mengetahui kesiapan mahasiswa LPTK di Semarang menjadi (calon) guru matematika yang profesional.

Penelitian dilaksanakan pada bulan AprilMei 2016 di dua LPTK swasta di Semarang yang memiliki program studi matematika dan telah meluluskan mahasiswanya.

Populasi penelitian ini adalah seluruh mahasiswa semester 8 program studi pendidikan matematika LPTK di Semarang. Sampel penelitian untuk pendekatan kuantitatif adalah 50 mahasiswa semester 8 LPTK di Semarang yang dipilih menggunakan teknik purposive sampling, kemudian dilanjutkan dengan stratified random sampling berdasarkan jumlah kelas pada setiap LPTK. Sampel untuk pendekatan kualitatif adalah 6 mahasiswa untuk teknik observasi dan 8 mahasiswa untuk teknik wawancara, yang dipilih menggunakan teknik purposive sampling.

Prosedur penelitian dengan sequential explanatory strategy disajikan pada Gambar 1 yang diadaptasi dari Creswell (2009, p.210). Pengumpulan data kuantitatif dilakukan dilakukan terlebih dahulu. Pengumpulan data kuantitatif dilakukan menggunakan tes dan angket, sedangkan pengumpulan data kualitatif dilakukan dengan telaah dokumen, observasi, dan wawancara.

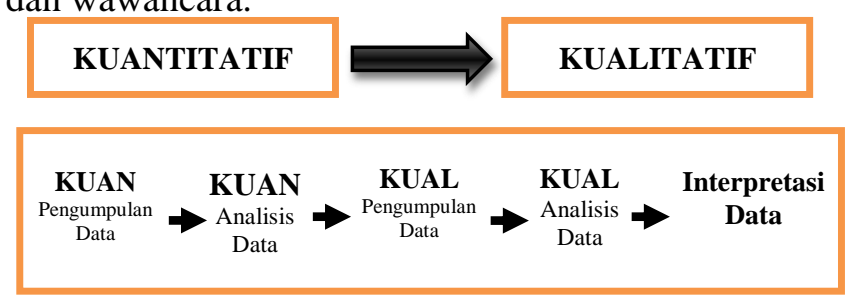

\section{Gambar 1. Prosedur Penelitian Model Sequential Explanatory Strategy}

Hasil analisis data kuantitatif digunakan sebagai dasar pengumpulan data kualitatif. Responden yang dipilih adalah responden yang memeroleh skor tes dan angket tertinggi dan terendah. Data kuantitatif dan kualitatif dianalisis untuk digabungkan dan dibandingkan, sehingga dapat ditemukan data kualitatif mana yang memperkuat, memperluas dan menggugurkan data kuantitatif. Data kuantitatif disajikan dalam bentuk tabel/grafik yang dilengkapi dengan data kualitatif. Setelah data diperoleh, selanjutnya dilakukan analisis dan penarikan kesimpulan.

\section{Data, Instrumen, dan Teknik Pengumpulan Data}

Kesiapan mahasiswa LPTK swasta di Semarang menjadi guru matematika yang profesional terdiri atas 3 aspek yaitu aspek pengetahuan, keterampilan, dan sikap. Aspek pengetahuan terdiri atas pengetahuan tentang konten matematika dan pengetahuan pedagogik. Instrumen untuk mengukur aspek ini adalah instrumen tes yang terdiri atas 40 soal objektif untuk pengetahuan konten matematika dan 30 soal objektif untuk pengetahuan pedagogik. Aspek keterampilan terdiri atas keterampilan menyiapkan pembelajaran dan melaksanakan pembelajaran.

Aspek selanjutnya yang diukur adalah aspek ketrampilan yang terdiri atas keterampilan menyiapkan dan melaksanakan pembelajaran. Instrumen nontes yang digunakan berupa angket 
penilaian diri, dengan 26 butir pernyataan untuk menilai keterampilan dalam menyiapkan pembelajaran dan 40 butir pernyataan untuk menilai keterampilan melaksanakan pembelajaran. Instrumen angket ini menggunakan skala Guttman dengan dua opsi jawaban. Selain angket, digunakan instrumen untuk telaah dokumen Rencana Pelaksanaan Pembelajaran (RPP) dan Lembar Kerja Siswa (LKS) untuk semua responden. Instrumen ini digunakan untuk mengukur keterampilan dalam menyiapkan pembelajaran. Terdapat juga instrumen pedoman observasi untuk mengukur keterampilan dalam melaksanakan pembelajaran.

Aspek selanjutnya yaitu sikap, terdiri atas keyakinan, persepsi, dan minat menjadi guru matematika yang profesional. Instrumen yang digunakan adalah instrumen non tes berupa angket yang terdiri atas 33 butir pernyataan angket keyakinan, 23 butir pernyataan angket persepsi, dan 26 butir pernyataan angket minat. Angket ini menggunakan skala Linkert. Instrumen terakhir dalam penelitian ini adalah instrumen pedoman wawancara yang digunakan untuk mengungkap semua aspek tersebut.

\section{Teknik Analisis Data}

Berdasarkan jenis datanya, teknik analisis data yang digunakan dalam penelitian ini adalah teknik analisis data deskriptif kuantitatif dan deskriptif kualitatif.

\section{Teknik Analisis Deskriptif Kuantitatif}

Analisis deskriptif kuantitatif yang disajikan dalam bentuk tabel, memuat nilai yang diperoleh responden yang telah dikonversikan ke dalam skala 0-100. Kesiapan mahasiswa ditentukan berdasarkan tingkat kecenderungan dengan melakukan kategorisasi pada masingmasing variabel. Berikut merupakan tabel kriteria pengkategorian nilai responden untuk masing-masing sub variabel.

Tabel 1. Kriteria Penilaian

\begin{tabular}{cc}
\hline Nilai & Kriteria \\
\hline$X>90$ & Sangat Siap \\
$75<X \leq 90$ & Siap \\
$60<X \leq 75$ & Cukup Siap \\
$50<X \leq 60$ & Kurang Siap \\
$X \leq 50$ & Sangat Kurang \\
\hline
\end{tabular}

Keterangan:

$X=($ skor responden/skor maksimum $) \times 100$

Teknik Analisis Deskriptif Kualitatif
Data kualitatif hasil telaah dokumen, observasi, dan wawancara dianalisis dengan model interaktif (interactive model) yang terdiri atas reduksi data (data reduction), penyajian data (data display) dan penarikan kesimpulan atau verifkasi (conclusion drawing and verification) (Miles \& Huberman, 1994, pp. 1012). Teknik analisis data tersebut dapat ditunjukkan dalam Gambar 2.

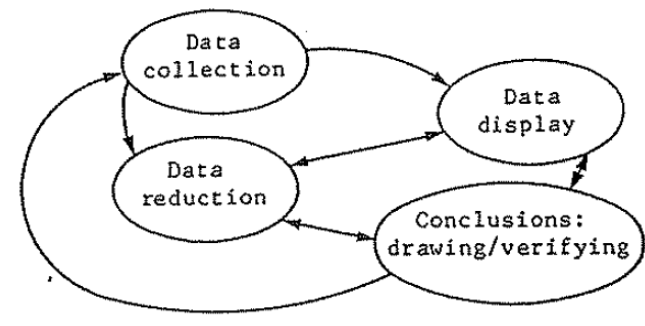

Gambar 2. Komponen Analisis Data Model Interaktif

Pada tahap reduksi data, dilakukan kegiatan merangkum, memilih hal-hal yang pokok, menyederhanakan, memfokuskan pada hal-hal penting untuk dicari tema dan polanya dan membuat abstraksi. Abstraksi merupakan usaha membuat rangkuman dari inti, proses, dan pernyataan-pernyataan yang perlu dijaga sehingga tidak mengubah makna. Selanjutnya, dilakukan penyajian data, dengan menyusun data yang telah direduksi ke dalam satuan-satuan. Yang dimaksud dengan satuan adalah informasi terkecil yang dapat berdiri sendiri dan dapat ditafsirkan tanpa informasi tambahan atau informasi yang mengarah pada satu pengertian atau satu tindakan yang berhubungan dengan penelitian ini. Penyajian data dapat dilakukan dengan teks yang bersifat naratif, grafik, matrik, network (jejaring kerja) dan chart. Penarikan kesimpulan dilakukan dengan cara malakukan kategorisasi, yaitu menyatukan data atau suatu informasi yang dirasa sama atau hampir sama dimasukkan dalam satu kategori. Kesimpulan awal yang dikemukakan masih bersifat sementara. Kesimpulan-kesimpulan sementara yang sudah didapatkan lalu diverifikasikan untuk mendapatkan kesimpulan yang kredibel.

\section{HASIL DAN PEMBAHASAN}

Secara umum hasil penelitian ini ditampilkan dalam Tabel 2. Berdasarkan Tabel 2 terlihat bahwa $26 \%$ dari 50 mahasiswa masuk dalam kategori siap. Sementara $70 \%$ dari 50 mahasiswa masuk dalam kategori cukup. Sedangkan sisanya $4,11 \%$ masuk dalam kategori kurang. Data tersebut menunjukkan bahwa tidak 
ada mahasiswa yang masuk dalam kategori sangat siap dan sangat kurang siap. Lebih dari $50 \%$ mahasiswa LPTK di semarang memiliki kesiapan dalam kategori cukup.

Tabel 2. Kesiapan Mahasiswa LPTK Swasta di Semarang Menjadi Guru Matematika yang Profesional

\begin{tabular}{cccc}
\hline Kriteria & Nilai & Jumlah & Presentase \\
\hline$X>90$ & Sangat Siap & 0 & $0 \%$ \\
$75<X \leq 90$ & Siap & 13 & $26 \%$ \\
$60<X \leq 75$ & Cukup Siap & 35 & $70 \%$ \\
$50<X \leq 60$ & Kurang Siap & 2 & $4 \%$ \\
$X \leq 50$ & Sangat Kuran & 0 & $0 \%$ \\
\hline \multicolumn{2}{c}{ Total } & $\mathbf{5 0}$ & $\mathbf{1 0 0 \%}$ \\
\hline
\end{tabular}

Berikut disajikan secara rinci data kompenen yang mendukung kesiapan mahasiswa LPTK di Semarang menjadi (calon) guru matematika yang profesional, yaitu kesiapan pengetahuan, keterampilan dan sikap mahasiswa LPTK di Semarang menjadi (calon) guru matematika yang profesional.

Pengetahuan Profesional

Pengetahuan profesional mahasiswa LPTK swasta di Semarang menjadi guru matematika yang profesional terdiri atas pengetahuan konten/materi matematika dan pengetahuan pedagogik. Distribusi frekuensi untuk komponen pengetahuan konten/materi dapat dilihat dalam Tabel 3 .

Tabel 3. Skor Pengetahuan Konten/Materi Matematika

\begin{tabular}{cccc}
\hline Kriteria & Nilai & Jumlah & Presentase \\
\hline$X>90$ & Sangat Siap & 0 & $0 \%$ \\
$75<X \leq 90$ & Siap & 8 & $16 \%$ \\
$60<X \leq 75$ & Cukup Siap & 10 & $20 \%$ \\
$50<X \leq 60$ & Kurang Siap & 10 & $20 \%$ \\
$X \leq 50$ & Sangat Kuran & 22 & $44 \%$ \\
\hline \multicolumn{2}{c}{ Total } & $\mathbf{5 0}$ & $\mathbf{1 0 0 \%}$ \\
\hline
\end{tabular}

Tabel 3 menunjukkan bahwa sebanyak 16\% mahasiswa memiliki pengetahuan konten/ materi yang masuk dalam kategori siap, sebanyak 20\% mahasiswa memiliki pengetahuan konten/materi yang masuk dalam kategori cukup, sebanyak 20\% mahasiswa memiliki kesiapan pengetahuan konten/materi yang masuk kategori kurang, dan sisanya sebanyak 44\% mahasiswa memiliki kesiapan pengetahuan konten/materi yang masuk dalam kategori sangat kurang untuk menjadi guru matematika yang profesional. Data pada Tabel 3 juga menunjukkan bahwa tidak ada mahasiswa yang memiliki pengetahuan konten/materi dengan kategori sangat baik. Berdasarkan Tabel 3 juga diperoleh bahwa presentase terbanyak adalah mahasiswa yang masuk dalam kategori sangat kurang untuk kesiapan pengetahuan konten/ materi yaitu hampir $50 \%$.

Distribusi frekuensi untuk komponen pengetahuan konten/materi dapat dilihat dalam Tabel 4.

Tabel 4. Skor Pengetahuan Pedagogik

\begin{tabular}{|c|c|c|c|}
\hline Kriteria & Nilai & Jumlah & Presentase \\
\hline$X>90$ & $\begin{array}{c}\text { Sangat } \\
\text { Siap }\end{array}$ & 0 & $0 \%$ \\
\hline $75<X \leq 90$ & Siap & 2 & $4 \%$ \\
\hline $60<X \leq 75$ & Cukup Siap & 5 & $10 \%$ \\
\hline $50<X \leq 60$ & $\begin{array}{c}\text { Kurang } \\
\text { Siap }\end{array}$ & 18 & $36 \%$ \\
\hline$X \leq 50$ & $\begin{array}{l}\text { Sangat } \\
\text { Kurang }\end{array}$ & 25 & $50 \%$ \\
\hline \multicolumn{2}{|c|}{ Total } & $\mathbf{5 0}$ & $100 \%$ \\
\hline
\end{tabular}

Tabel 4 menunjukkan bahwa sebanyak 4\% mahasiswa memiliki pengetahuan pedagogik dalam kategori siap, $10 \%$ mahasiswa memiliki pengetahuan pedagogik dalam kategori cukup, $36 \%$ mahasiswa memiliki pengetahuan pedagogik dalam kategori kurang, dan sisanya, sebanyak 50\% mahasiswa memiliki pengetahuan pedagogik dalam kategori sangat kurang untuk menjadi guru matematika yang profesional.

Berdasarkan perolehan data, terlihat bahwa tidak ada mahasiswa yang memiliki pengetahuan pedagogik dalam kategori sangat baik. Secara umum, dapat disimpulkan bahwa pengetahuan konten materi dan pedagogik mahasiswa LPTK swasta di Semarang untuk menjadi guru matematika profesional masuk dalam kategori kurang.

Keterampilan Profesional

Tabel 5. Skor Keterampilan Menyiapkan Pembelajaran

\begin{tabular}{cccc}
\hline Kriteria & Nilai & Jumlah & Presentase \\
\hline$X>90$ & Sangat Siap & 6 & $12 \%$ \\
$75<X \leq 90$ & Siap & 18 & $36 \%$ \\
$60<X \leq 75$ & Cukup Siap & 13 & $26 \%$ \\
$50<X \leq 60$ & Kurang Siap & 3 & $6 \%$ \\
$X \leq 50$ & Sangat Kurang & 0 & $0 \%$ \\
\hline \multicolumn{2}{c}{ Total } & $\mathbf{5 0}$ & $\mathbf{1 0 0 \%}$ \\
\hline
\end{tabular}

Keterampilan profesional mahasiswa LPTK swasta di Semarang untuk menjadi guru matematika yang profesional terdiri atas keterampilan menyiapkan dan melaksanakan pembelajaran. Distribusi frekuensi komponen 
keterampilan menyiapkan pembelajaran dapat dilihat pada Tabel 5.

Berdasarkan Tabel 5, terlihat bahwa sebanyak $12 \%$ mahasiswa memiliki keterampilan menyiapkan pembelajaran dalam kategori sangat siap, 36\% mahasiswa memiliki keterampilan menyiapkan pembelajaran dalam kategori siap, $26 \%$ mahasiswa memiliki keterampilan menyiapkan pembelajaran dalam kategori cukup, dan sisanya, sebanyak $6 \%$ mahasiswa memiliki kesiapan keterampilan menyiapkan pembelajaran dalam kategori kurang untuk menjadi guru matematika yang profesional.

Berdasarkan Tabel 5, terlihat bahwa tidak ada mahasiswa yang memiliki keterampilan menyiapkan pembelajaran dengan kategori sangat kurang. Dapat disimpulkan bahwa mahasiswa dengan kesiapan keterampilan menyiapkan pembelajaran dalam kategori siap mencapai persentase terbanyak, yaitu $36 \%$.

Distribusi frekuensi untuk komponen keterampilan melaksanakan pembelajaran dapat dilihat dalam Tabel 6.

Tabel 6. Skor Keterampilan Melaksanakan Pembelajaran

\begin{tabular}{cccc}
\hline Kriteria & Nilai & Jumlah & Presentase \\
\hline$X>90$ & Sangat Siap & 18 & $36 \%$ \\
$75<X \leq 90$ & Siap & 32 & $64 \%$ \\
$60<X \leq 75$ & Cukup Siap & 0 & $0 \%$ \\
$50<X \leq 60$ & Kurang Siap & 0 & $0 \%$ \\
$X \leq 50$ & Sangat Kurang & 0 & $0 \%$ \\
\hline \multicolumn{2}{c}{ Total } & $\mathbf{5 0}$ & $\mathbf{1 0 0 \%}$ \\
\hline
\end{tabular}

Berdasarkan Tabel 6, terlihat bahwa sebanyak 36\% mahasiswa memiliki keterampilan melaksanakan pembelajaran dalam kategori sangat siap, 64\% mahasiswa memiliki keterampilan melaksanakan pembelajaran dalam kategori siap.

Data pada Tabel 6 menunjukkan bahwa tidak ada mahasiswa yang memiliki keterampilan melaksanakan pembelajaran dengan kategori cukup, kurang, dan sangat kurang. Data tersebut juga menunjukkan bahwa lebih dari 50\% mahasiswa memiliki keterampilan melaksanakan pembelajaran dalam kategori siap. Secara umum, keterampilan mahasiswa LPTK swasta di Semarang menjadi guru matematika profesional jika ditinjau dari keterampilan menyiapkan dan melaksanakan pembelajaran termasuk dalam kategori siap. Hal tersebut sejalan dengan hasil penelitian Gito, Ramdani, Jamaluddin, \& Akhmad (2016, pp.294-195) bahwa mahasiswa calon guru matematika sudah baik dalam menyiapkan dan melaksanakan pembelajaran, meskipun ada beberapa kendala.

\section{Sikap Profesional}

Sikap profesional mahasiswa LPTK swasta di Semarang terdiri atas keyakinan, persepsi, dan minat menjadi guru matematika yang profesional. Distribusi frekuensi untuk komponen keyakinan menjadi guru matematika yang profesional dapat dilihat dalam Tabel 7.

Tabel 7. Skor Keyakinan Menjadi Guru Matematika yang Profesional

\begin{tabular}{cccc}
\hline Kriteria & Nilai & Jumlah & Presentase \\
\hline$X>90$ & Sangat Siap & 4 & $8 \%$ \\
$75<X \leq 90$ & Siap & 33 & $66 \%$ \\
$60<X \leq 75$ & Cukup Siap & 12 & $24 \%$ \\
$50<X \leq 60$ & Kurang Siap & 1 & $2 \%$ \\
$X \leq 50$ & Sangat Kurang & 0 & $0 \%$ \\
\hline \multicolumn{2}{c}{ Total } & $\mathbf{5 0}$ & $\mathbf{1 0 0 \%}$ \\
\hline
\end{tabular}

Berdasarkan Tabel 7, terlihat bahwa sebanyak $8 \%$ mahasiswa memiliki keyakinan dalam kategori sangat siap, 66\% mahasiswa memiliki keyakinan dalam kategori siap, 24\% mahasiswa memiliki keyakinan dalam kategori cukup, dan sisanya, sebanyak $2 \%$ mahasiswa memiliki keyakinan dalam kategori kurang untuk menjadi guru matematika yang profesional. Terlihat bahwa tidak ada mahasiswa yang memiliki keyakinan dalam kategori sangat kurang. Berdasarkan Tabel 7, dapat disimpulkan bahwa lebih dari 50\% mahasiswa memiliki keyakinan untuk menjadi guru matematika profesional dalam kategori siap.

Distribusi frekuensi untuk komponen persepsi menjadi guru matematika yang profesional dapat dilihat dalam Tabel 8 .

Tabel 8. Skor Persepsi Menjadi Guru Matematika yang Profesional

\begin{tabular}{clcc}
\hline Kriteria & Nilai & Jumlah & Presentase \\
\hline$X>90$ & Sangat Siap & 2 & $4 \%$ \\
$75<X \leq 90$ & Siap & 24 & $48 \%$ \\
$60<X \leq 75$ & Cukup Siap & 24 & $48 \%$ \\
$50<X \leq 60$ & Kurang Siap & 0 & $0 \%$ \\
$X \leq 50$ & Sangat Kuran & 0 & $0 \%$ \\
\hline \multicolumn{2}{c}{ Total } & $\mathbf{5 0}$ & $\mathbf{1 0 0 \%}$ \\
\hline
\end{tabular}

Tabel 8 menunjukkan bahwa sebanyak 4\% mahasiswa memiliki persepsi dalam kategori sangat siap, $48 \%$ mahasiswa memiliki persepsi dalam kategori siap dan sisanya, $48 \%$ mahasiswa memiliki persepsi dalam kategori cukup untuk menjadi guru matematika yang profesional. Terlihat bahwa tidak ada mahasiswa yang memiliki persepsi dengan kategori kurang dan sangat kurang. Berdasarkan Tabel 8, 
persentase terbanyak dicapai oleh mahasiswa yang masuk dalam kategori siap dan cukup untuk persepsi menjadi guru matematika yang profesional yaitu sebesar $48 \%$.

Distribusi frekuensi untuk komponen minat menjadi guru matematika yang profesional dapat dilihat dalam Tabel 9.

Tabel 9. Skor Minat Menjadi Guru Matematika yang Profesional

\begin{tabular}{cccc}
\hline Kriteria & Nilai & Jumlah & Presentase \\
\hline$X>90$ & Sangat Siap & 1 & $2 \%$ \\
$75<X \leq 90$ & Siap & 23 & $46 \%$ \\
$60<X \leq 75$ & Cukup Siap & 24 & $48 \%$ \\
$50<X \leq 60$ & Kurang Siap & 2 & $4 \%$ \\
$X \leq 50$ & Sangat Kuran: & 0 & $0 \%$ \\
\hline \multicolumn{2}{c}{ Total } & $\mathbf{5 0}$ & $\mathbf{1 0 0 \%}$ \\
\hline
\end{tabular}

Tabel 9 menunjukkan bahwa sebanyak $2 \%$ mahasiswa memiliki minat dalam kategori sangat siap, $46 \%$ mahasiswa memiliki minat dalam kategori siap, 48\% mahasiswa memiliki minat dalam kategori cukup, dan sisanya, sebanyak $4 \%$ mahasiswa memiliki minat dalam kategori kurang untuk menjadi guru matematika yang profesional. Terlihat bahwa tidak ada mahasiswa yang memiliki keyakinan dengan kategori sangat kurang.

Berdasarkan Tabel 9, presentase terbesar dicapai oleh mahasiswa yang memiliki kesiapan minat menjadi guru matematika profesional, yaitu sebesar 36\%. Secara umum, sikap mahasiswa LPTK swasta di Semarang untuk menjadi guru matematika professional, yang terdiri atas keyakinan, persepsi dan minat masuk dalam kategori siap.

Hasil Observasi dan Wawancara

Observasi dilakukan kepada 6 responden yang merupakan sampel dalam penelitian. Sedangkan wawancara dilakukan kepada 8 responden. Hasil analisis observasi dan wawancara disajikan pada Tabel 10.

Komponen-komponen pada Tabel 10 didukung oleh hasil telaah dokumen rencana pelaksanaan pembelajaran (RPP) dan lembar kerja siswa (LKS) serta wawancara yang dilakukan oleh peneliti. Hasil telaah dokumen yang telah dilakukan menunjukkan bahwa kesiapan mahasiswa LPTK di Semarang menjadi (calon) guru matematika masuk dalam kategori cukup. Dokumen yang digunakan pada tahap telaah dokumen adalah RPP dan LKS untuk satu kali pertemuan.

Rencana pelaksanaan pembelajaran (RPP) dan lembar kerja siswa (LKS) yang ditelaah merupakan RPP dan LKS yang digunakan responden sebagai perangkat dalam melaksanakan microteaching dan magang mengajar. Sebagian besar RPP dan LKS sudah melalui beberapa revisi yang dilakukan oleh responden berdasarkan arahan dosen dan guru pendamping, sehingga kualitas RPP dan LKS masuk dalam kategori siap. Meskipun demikian, masih terdapat beberapa RPP dan LKS yang masih terkategori cukup dan kurang. Beberapa mahasiswa belum menulis dengan detail kegiatan yang ada di RPP, sehingga yang tertulis pada RPP hanya berupa garis besar kegiatan. Selain itu, beberapa responden juga belum menggunakan kata kerja operasional dalam menyusun rumusan indikator. Sementara itu, masih banyak LKS yang belum sesuai dengan RPP yang dibuat, terutama keselarasan model/metode/pendekatan yang digunakan dalam RPP belum terintegrasi pada LKS. LKS yang dibuat hanya berisikan soal-soal tanpa adanya langkah kerja siswa yang disesuaikan dengan model/metode yang dipilih.

Berdasarkan hasil wawancara dengan delapan responden diperoleh informasi bahwa ada beberapa materi matematika yang masih belum dipahami secara maksimal. Beberapa materi tersebut adalah geometri, trigonometri dan peluang. Materi tersebut juga mempengaruhi responden dalam mengajarkannya. Alasan responden sulit memahami materi geometri adalah karena materi geometri harus memiliki kemampuan berpikir abstrak yang baik. Pada materi trigonometri, responden menganggap bahwa materi ini banyak menggunakan rumus hafalan sehingga masih merasa kesulitan dalam memahaminya. Sementara pada materi peluang, responden merasa bahwa permasalahan pada materi ini sangat luas sehingga membutuhkan kemampuan logika yang matang.

Hasil wawancara juga menunjukkan bahwa responden masih kurang memiliki pengetahuan tentang karakteristik siswa dan kurikulum. Berkaitan dengan hal tersebut, alasan yang dikemukakan oleh responden adalah karena heterogenitas siswa yang tinggi dan tingkat intelektual yang beragam juga. Secara teoritis, beberapa responden mengaku bahwa masih belum secara maksimal memahami psikologi belajar anak. Selain itu, beberapa responden juga masih belum memiliki pengetahuan tentang kurikulum yang matang. Beberapa perubahan pada kurikulum menjadi alasan mengapa responden belum antusias untuk memahami kurikulum. 
Pythagoras, 12 (1), 2017 - 95

Saifan Sidiq Abdullah

Tabel 10. Hasil Analisis Data Observasi dan Wawancara

\begin{tabular}{|c|c|c|c|}
\hline Hasil Reduksi dan Penyajian Data & Tema & $\begin{array}{l}\text { Keterkaitan } \\
\text { antar Tema }\end{array}$ & Kesimpulan \\
\hline $\begin{array}{l}\text { Kesulitan dalam memahami materi } \\
\text { peluang dan trigonometri }\end{array}$ & $\begin{array}{l}\text { Pengetahuan } \\
\text { konten/materi }\end{array}$ & \multirow[b]{2}{*}{$\begin{array}{l}\text { Pengetahuan } \\
\text { Profesional }\end{array}$} & \multirow{12}{*}{$\begin{array}{l}\text { Kesiapan mahasiswa LPTK } \\
\text { swasta di Semarang menjadi guru } \\
\text { matematika yang profesional dari } \\
\text { aspek pengetahuan masih kurang, } \\
\text { baik pengetahuan konten/materi } \\
\text { matematika maupun pedagogik, } \\
\text { sementara keterampilan } \\
\text { menyusun RPP dan LKS sudah } \\
\text { baik meskipun masih ada } \\
\text { beberapa kendala terutama dalam } \\
\text { menyusun kegiatan pada RPP, } \\
\text { LKS dan mengatur kondisi kelas, } \\
\text { begitu juga dengan sikap } \\
\text { mahasiswa terhadap profesi guru } \\
\text { sudah baik, beberapa responden } \\
\text { merasa profesi guru } \\
\text { membanggakan, meskipun } \\
\text { beberapa mahasiswa berpendapat } \\
\text { bahwa menjadi guru itu sulit dan } \\
\text { belum memahami regulasi guru, } \\
\text { selain itu ada juga responden } \\
\text { yang berpendapat bahwa perlu } \\
\text { adanya peningkatan kualitas } \\
\text { dosen }\end{array}$} \\
\hline $\begin{array}{l}\text { Tidak memahami kurikulum secara } \\
\text { maksimal } \\
\text { Belum mehamami pengetahuan } \\
\text { tentang karakteristik siswa dan } \\
\text { penilaian }\end{array}$ & $\begin{array}{l}\text { Pengetahuan } \\
\text { pedagogik }\end{array}$ & & \\
\hline $\begin{array}{l}\text { RPP yang dibuat oleh responden } \\
\text { sudah baik secara komponen dan } \\
\text { kualitas }\end{array}$ & \multirow{3}{*}{$\begin{array}{l}\text { Keterampilan } \\
\text { menyiapkan } \\
\text { pembelajaran }\end{array}$} & \multirow{5}{*}{$\begin{array}{l}\text { Keterampilan } \\
\text { Profesional }\end{array}$} & \\
\hline $\begin{array}{l}\text { Banyak LKS yang kurang sesuai } \\
\text { dengan RPP terutama pada } \\
\text { kesesuaian metode pembelajaran } \\
\text { yang digunakan }\end{array}$ & & & \\
\hline $\begin{array}{l}\text { Kesulitan dalam menyusun langkah } \\
\text { pembelajaran dan alokasi waktu }\end{array}$ & & & \\
\hline $\begin{array}{l}\text { Pelaksanaan pembelajaran sudah } \\
\text { cukup sesuai dengan RPP yang } \\
\text { dibuat }\end{array}$ & \multirow{2}{*}{$\begin{array}{l}\text { Keterampilan } \\
\text { melaksanakan } \\
\text { pembelajaran }\end{array}$} & & \\
\hline $\begin{array}{l}\text { Belum luwes dalam mengondisikan } \\
\text { kelas }\end{array}$ & & & \\
\hline $\begin{array}{l}\text { Masih mengalami kendala terhadap } \\
\text { beberapa materi dan karakteristik } \\
\text { siswa }\end{array}$ & \multirow{2}{*}{$\begin{array}{l}\text { Keyakinan } \\
\text { terhadap diri dan } \\
\text { LPTK }\end{array}$} & \multirow{5}{*}{$\begin{array}{l}\text { Sikap } \\
\text { Profesional }\end{array}$} & \\
\hline $\begin{array}{l}\text { Perlu adanya peningkatan kualitas } \\
\text { dosen }\end{array}$ & & & \\
\hline $\begin{array}{l}\text { Menjadi guru sangat sulit sementara } \\
\text { menjadi guru honorer kurang } \\
\text { menjanjikan }\end{array}$ & \multirow{2}{*}{$\begin{array}{l}\text { Persepsi terhadap } \\
\text { profesi guru }\end{array}$} & & \\
\hline $\begin{array}{l}\text { Guru adalah profesi yang } \\
\text { membanggakan dan mulia }\end{array}$ & & & \\
\hline $\begin{array}{l}\text { Belum berminat untuk memahami } \\
\text { regulasi profesi guru }\end{array}$ & $\begin{array}{l}\text { Minat terhadap } \\
\text { regulasi guru }\end{array}$ & & \\
\hline
\end{tabular}

Beberapa kendala yang dialami responden dalam menyusun RPP adalah dalam menyusun langkah-langkah kegiatan pembelajaran yang efektif dan kesesuaian antara alokasi waktu dan materi yang akan diajarkan. Selain itu, kendala yang dialami oleh semua responden dalam melaksanakan pembelajaran adalah kesulitan dalam mengondisikan kelas. Beberapa responden menyatakan bahwa dirinya kurang tegas terhadap murid ketika suasana kelas mulai tidak kondusif. Beberapa alasan lain yang diungkapkan oleh responden berhubungan dengan pengetahuan responden tentang karakteristik siswanya yang masih kurang.

Dari ranah sikap, sebagian besar responden sudah memiliki keyakinan yang kuat untuk menjadi guru matematika yang profesional. Meskipun demikian, masih terdapat beberapa keraguan pada diri responden. Sebagian besar keraguan tersebut adalah keraguan diri terhadap materi/konten matematika dan pengalaman mengajar yang masih sangat kurang. Keraguan lainnya berkaitan dengan persepsi terhadap profesi guru. Sebagian besar responden menyatakan bahwa profesi guru saat ini sangat sulit didapatkan. Lulusan guru matematika yang semakin banyak tidak diimbangi dengan lapangan kerja yang memadai, sementara menjadi guru honorer menurutnya kurang menjanjikan. Beberapa responden juga menyatakan bahwa untuk menjadi guru honorer saja sekarang sulit. Informasi tentang lowongan guru di sekolah dirasa tidak transparan dan hanya menyebar di kalangan sekolah saja. Hal ini juga menjadi salah satu alasan mengapa banyak lulusan pendidikan matematika yang beralih pada pekerjaan lain. Seharusnya dinas pendidikan pada setiap kabupaten berkoordinasi dengan pihak sekolah untuk selalu memperbarui informasi tentang kebutuhan guru ketika ada guru 


\section{Pythagoras, 12 (1), 2017 - 96 \\ Saifan Sidiq Abdullah}

yang pensiun atau mutasi. Dengan demikian, diharapkan sekolah mampu menyeleksi calon guru dengan baik sehingga guru yang mengajar di sekolah tersebut adalah guru-guru yang berkualitas.

Masalah tentang ketersediaan lapangan pekerjaan bagi mahasiswa calon guru sebenarnya dapat diatasi melalui beberapa strategi. Salah satunya adalah dengan diadakannya program-program seperti SM3T oleh Dinas Pendidikan kabupaten/kota atau provinsi pada setiap wilayahnya. Dinas Pendidikan harus berkoordinasi dengan pihak LPTK untuk memantau mahasiswa yang berasal dari daerahnya, kemudian dilakukan seleksi terhadap lulusan mahasiswa calon guru. Bagi mahasiswa calon guru yang tidak lolos kemudian direkomendasikan untuk mengikuti program SM3T. Selain mengatasi masalah ketersediaan pekerjaan guru, diharapkan program ini dapat mengatasi masalah kesetaraan pendidikan di Indonesia.

Alasan responden memilih jurusan pendidikan matematika adalah karena mereka menyukai ilmu hitung dan hampir semua responden menyatakan berminat menjadi guru matematika. Ketika diminta untuk memberikan saran untuk LPTK, sebagian besar responden menyakatan bahwa perlu peningkatan kualitas dosen. Selain itu, beberapa responden menyatakan bahwa mereka masih kurang dibekali pengetahuan tentang penelitian. Meskipun demikian, ada responden yang menyatakan bahwa LPTK harus bisa mempertahankan kualitasnya.

\section{SIMPULAN}

Berdasarkan hasil penelitian dan pembahasan, dapat disimpulkan bahwa kesiapan mahasiswa LPTK swasta di Semarang menjadi guru matematika yang profesional masuk dalam kategori cukup. Pengetahuan profesional yang terdiri atas pengetahuan konten matematika dan pedagogik terkategori kurang. Keterampilan profesional yang meliputi keterampilan menyiapkan dan melaksanakan pembelajaran terkategori siap. Sikap profesional yang meliputi keyakinan, persepsi dan minat menjadi guru matematika yang profesional terkategori siap. Terdapat beberapa kendala terutama pada aspek pengetahuan dan keterampilan profesional antara lain (1) terdapat materi pembelajaran yang masih sulit dipahami oleh responden, yaitu materi peluang dan trigonometri; (2) masih kurangnya pengetahuan tentang karaktersitik siswa, kurikulum dan penilaian; (3) kesulitan dalam menyusun langkah-langkah pembelajaran dan alokasi waktu pada RPP serta menyesuaikan LKS dengan RPP yang sudah dibuat; (4) kesulitan dalam mengondisikan kelas selama kegiatan pembelajaran.

\section{DAFTAR PUSTAKA}

Azhar. (2009). Kondisi LPTK sebagai pencetak guru yang profesional. Jurnal Tabularasa PPs UNIMED, 6, 1-13.

Chotimah, U. (2009). Peranan LPTK dalam mewujudkan guru yang profesional: suatu tantangan dan harapan. Seminar Nasional Pendidikan yang diselenggarakan oleh Universitas Sriwijaya, tanggal $14 \mathrm{Mei}$ 2009. Palembang: Universitas Sriwijaya.

Creswell, J. D. (2009). Research design (qualitative, quantitative and mixed methods approaches). Thousand Oaks, CA: Sage Publications Ltd.

Gito, H., Ramdani, A., Jamaluddin, Karnan, \& Akhmad S. (2016). Kompetensi profesional dan pedagogi dalam pelaksanaan program pengalaman lapangan. Cakrawala Pendidikan, 15(2). doi:http://dx.doi.org/10.21831/cp.v15i2.8 093

Hilgard, E. R. \& Bower, G. H. (1975). Theories of learning $\left(4^{\text {th }} e d\right)$. New Jersey: PrenticeHall, Inc.

Jusoh, R. (2012). Effect of teachers' readiness in teaching and learning of interpreunership education in primary schools. International Interdisciplinary Journal of Education, 7(1), 98-102.

Menteri Pendidikan. (2006). Peraturan menteri nomor 22, tahun 2006, tentang standar isi untuk satuan pendidikan dasar dan menengah.

Menteri Pendidikan. (2009). Peraturan menteri nomor 8, tahun 2009, tentang program pendidikan profesi guru pra jabatan.

Miles, M. B \& Huberman, A.M. (1994). Qualitative data anlysis. California: SAGE Publications.

Mulyasa, E. (2013). Standar kompetensi dan sertifikat guru. Bandung: ROSDA.

Muzaffar, I., Rahim, H., \& Jessee, C. (2011). Designing effective pre-service teacher education pragrams. Washington, DC: USAID. 
NCTM. (2000). Principles and standars for school mathematics. Reston: NCTM.

Republik Indonesia. (2003). Undang-Undang RI Nomor 20, tahun 2003, tentang sistem pendidikan nasional.

Republik Indonesia. (2005). Undang-Undang RI nomor 14, tahun 2005, tentang guru dan dosen.

Rusman. (2010). Model-model pembelajaran: mengembangkan profesionalisme guru (edisi ke-2). Depok: PT Rajagrafindo Persada.

Smith, K. (2005). Professional standar for teachers: guidelines for professional practice. Brisbane: The State of Queensland.

Supriyo. (2015). Motivasi kerja guru SMP di Kota Semarang. Cakrawala Pendidikan, 34(1), 24-33.
Syah, M. (2013). Psikologi pendidikan: dengan pendekatan baru (edisi revisi). Bandung: PT Remaja Rosdakarya.

Townsend, T. \& Bates, R. (2007). Handbook of teacher education: globalization, standards and professionalism in times of change. Dordrecht: Springer.

Wibowo, E., \& Jailani, J. (2014). analisis kesulitan guru matematika SMP dalam pengembangan profesi di Kabupaten Wonosobo. Jurnal Riset Pendidikan Matematika, $\quad$ 1(2), 202-215. doi:http://dx.doi.org/10.21831/jrpm.v1i2. 2676

Widyani, M. H. (2010). Evaluating teacher' quality improvement policy in Indonesia (to meet the UNESCO-EFA criteria). Tesis master, tidak diterbitkan, Delft University of Technology, Belanda. 